\title{
Multiethnic Value in Dodogeran Dance
}

\author{
Elia Nurih Saniati*, Juju Masunah \\ Department of Art Education \\ Universitas Pendidikan Indonesia \\ Bandung Indonesia \\ *elianurihsaniati@upi.edu
}

\begin{abstract}
Dodogeran dance is a dance originating from the city of Bekasi, a city that has many urban settlements from various ethnic groups. Eem Biliyanti created Dodogeran Dance, originating from three ethnic groups in Bekasi, namely Betawi, Sundanese and Chinese. The purpose of this study was to analyze the multiethnic values contained in Dodogeran's dance. This research uses descriptive analysis method. Data collection is done through interviews, observations, documentation studies, and literature review. Data analysis is conducted by triangulation to describe the background and the process of creating the Dodogeran dance and the multiethnic values contained in the Dodogeran dance. The results of this study conclude that the multiethnic value in the Dodogeran dance lies in the Sundanese ethnic motives including the pakblang, silat, and Betawi ethnic movements namely rapet nindak. The costume in the dodogeran dance consists of pangsi pants such as Sundanese ethnic, sash toka-toka, andong rawis such as ethnic Betawi, hairpin Chinese. Dodogeran dance music adapted from the Betawi mask with fast tempo. Dodogeran dance is a form of acculturation in Bekasi which has become its own culture identity.
\end{abstract} Bekasi

Keywords-Dodogeran dance, multiethnic value, multiculture,

\section{INTRODUCTION}

Indonesia is an archipelago that has a diversity of cultures, races, ethnicities, creeds, religions and languages. Indonesia consists of many ethnicities, cultures, languages and a variety of characters possessed by its people [1]. Ethnicity is often equated with race because in certain ethnic groups there are elements of race or vice versa [2]. However, ethnicity is a group of people who share a common history of ancestors, values, languages, and customs. Indonesian people are multiethnic people [3]. Even so the local people themselves do not necessarily know the ethnicity that exists in the environment where they live. If this kind of spirit and attention to diversity internalized in every person to create harmony and harmony with a lifestyle of mutual respect, then this behavior become the basic of realization of multiculturalism [4].

Each tribe can respect other tribes, let the community be given an understanding of ethnicity [5]. An understanding of ethnicity is found in the Dodogeran Dance, because the dance is a special attraction to overcome the problem that currently faced by the Indonesian people, regarding to Indonesia's diversity which does not always create beauty, uniqueness and other positive things. This diversity also has the potential to be a threat. The threat in the form of separation between groups, social jealousy and so on. Threats or conflicts that occur in Indonesia actually do not originate from the differences themselves, but there are misunderstandings arising from communication. In order not to create such misunderstanding, the awareness to appreciate, respecting and upholding the principle of equality must be created. When such awareness is created, between individuals and groups, can get to know each other, understand, appreciate and communicate with each other.

Bekasi City is one of the cities in the province of West Java, Indonesia. Currently, Bekasi City has developed into a residence for urbanites and industrial centers. Bekasi City is also dubbed the City of Patriots and City of Warior/Fighters. The culture in Bekasi city is quite diverse which has a mixture of several cultures. The geographical location of Bekasi City is between Sundanese, Betawi, and the legacy of Chinese culture, this causes the art that resides in Bekasi to be a great extent the mixing of various cultures found in Bekasi and results in cultural aculturation. That makes Bekasi City has many urban settlements, so there are many diverse ethnicities, as migrants from various regions. An artist from Bekasi named Eem Biliyanti made a dance work, the Dodogeran dance as a Bekasi identity that reflects multi-ethnicity. Dodogeran dance is a dance that consists of three ethnic groups namely, Betawi, Sundanese and Chinese or Chinese. Betawi and Sundanese ethnic groups can be seen and heard from motion, costume and music. In this dance, Chinese ethnic can be seen from the costume. The three ethnic groups live in Bekasi City.

The Dodogeran dance once broke the Indonesian World Record Museum (MURI) record as the most dancers participating, totaling 3,317 people from 110 elementary schools in Bekasi City on March 10, 2014 in order to enliven the $17^{\text {th }}$ anniversary of Bekasi City. However, Dodogeran dance is more often used for welcoming dance at certain events. Because Dodogeran dance is a dance of creation that is rarely known by many people.

One of the efforts in introducing the ethnic groups in the area of residence is through a Dodogeran dance work. The 
dance work can be applied in schools to introduce the ethnicities contained in the work.

From the above background, various problems in this research can be formulated What is the history of the Dodogeran dance? What about make-up and costume, as well as Dodogeran dance music? What about the multi-ethnic value contained in the Dodogeran dance moving. The purpose of this study was to determine the history of Dodogeran dance make up and fashion, as well as Dodogeran dance music. Then, the researcher will analyze the multi-ethnic values contained in the Dodogeran dance. With this study, it is hoped that this research will be useful for artists, art teachers, and the communities so that differences can be appreciated and tolerance develops with others.

\section{MethodS}

This study uses a qualitative paradigm, with a descriptive analysis method. Participants involved in studying Dodogeran dance are the owner and creator of the Dodogeran dance at Sanggar Sinar Seli Asih. Sanggar Sinar is led by Sukarsa Suwarta Putra and his wife who created the Dodogeran dance named Eem Billiyanti.

Data collection techniques carried out through observations, interviews, and documentations. Observations were made on December 15, 2019 at Sanggar Sinar Seli asih Bekasi City. Interviews were conducted with the studio owners and dance creators of Dodogeran to get data on Dodogeran dance, the documents observed were Dodogeran dance motives, costume, music and the inter-relationships of various ethnicities contained in the Dodogeran dance.

Data analysis techniques used in this study used data triangulation, namely, data reduction from interviews, observations, and documentation studies, presentation and verification data [6]. The data reduction phase is carried out by examining all available data from various sources, namely interviews and observations in the field, so that the main points related to the analysis of the Dodogeran dance are found. After the data reduction process, the next step is the data presentation stage. The most often presentation used to present data in qualitative research is the narrative text. Presentation of data carried out in this study by describing the results of research on the Dodogeran dance based on text and context [6].

The third step in analyzing qualitative research data is drawing conclusions or verification. The conclusion in qualitative research is a new finding that has never existed before [6]. The findings can be in the form of a description, a description of an object that was previously unclear then after being examined becomes clearer, can be a causal or interactive relationship, as well as a hypothesis or theory.

Verification of data in this study is to draw conclusions from the overall results of the research regarding multiethnic information contained in the Dodogeran Dance.

\section{RESULTS AND DISCUSSION}

\section{A. Profile of Sinar Seli Asih Studio}

Sanggar Seli Asih was founded by Suwarta Seli in 1991. The name Seli is taken from the name of Suwarta Seli's father, that is, father Seli and Asih has a love or everlasting meaning. The late Mr. Seli Bin Boan and the late Mrs. Nisah Binti Juin were the first founders of this arts group. Mr. Seli is from the Karawang area, while Ms. Nisah is from the Tambun area of Bekasi. Mr. Seli is a fiddle player (stringed instrument) in the Ubrug Mask group, while Ms. Nisah is a mask dancer. In 1918 Mr. Seli founded a mask group that he had long dreamed of even though he only capitalized a simple musical instrument called the mask Seli. By the time the Seli mask group was formed, Mr. seli and Mrs. Nisah were already living in Tambun, Bekasi. After many people are interested and familiar with this group, then naturally many people mention the name of this group is associated with the name of the region, namely the mask group leader Tambun seli. Towards his old age, Mr. Seli diligently educated his children namely Nalem, Nata, Marta, Suwarta and Warnih in order to trained them to become the next generation of art that he had pioneered. Around 1962, Mr. Seli passed away and the leadership of the Seli mask group was handed over to his third son, Marta Seli. This studio operates in the dance and music tradition of the Bekasi Topeng tradition which carries the Little Mask group with members consisting of the grandson and great-grandson of Mr. Seli. The father of Suwarta Seli in 2007, the group leadership was continued by his son, Sukarsa Suwarta Putra. During the Sukarsa leadership, the name of the group changes to Sinar Seli Asih.

\section{B. Dodogeran Dance}

The Dodogeran dance was created by a choreographer named Eem Biliyanti from the Bekasi Seli Asih Studio. Dodogeran dance created by artists from the city of Bekasi, it is an art that contain a lot of local wisdom, many ethnicities are available from a variety of movements, costume, and music. For appreciate art, someone must understand the art itself Where (region / culture, the supporting community), the art originated, when it was created, who was the creator, how the art looks and so on. To get a comprehensive understanding of ethnic dance, it is necessary to study and among others with an ethno-choreological approach [7]. Ethnocoreology comes from the word ethno which means ethnicity, choreo means dance. Thus ethnocoreology implies the knowledge of ethnic dances.

Dodogeran Dance is a New Creation Dance which is based on the mask dance movement which was developed into a new movement. The creation of this dance was inspired by the cuteness of children and the agility of teenagers in everyday life.

Motive motions in the Dodogeran dance: geol, pakblang, gagahan, silat, puter koma, rapet nindak variasi goyang, rapet nindak variasi, koma putes, kagok puter, nindak kagok goyang kaget, nindak kagog lenggang, ali and alimudin, kewer variasi. 
Costume in the Dodogeran dance consists of short-sleeved, balloon clothes, pangsi pants, toka-toka, Betawi sash, balloon costume, andong rawis such as ethnic Betawi, waistband, bunny bun, big flower and wool braids, skewers. Dodogeran dance music adapts from a Betawi mask and fast tempo.

\section{The Function of Dodogeran Dance in the Community}

Along with the development of the era several art functions have been formed in Indonesian society. the function of art as follows: Each era, each ethnic group, as well as every community environment, each form of performance art has different primary and secondary functions. However, in general the performing arts have three primary functions, namely (1) as a means of ritual; (2) as personal entertainment; and (3) as aesthetic percentage [8].

As contained in the Dodogeran dance has a function in the community that is seen in every event one of them in order to enliven the $17^{\text {th }}$ anniversary of Bekasi City on March 10, 2014, thousands of Bekasi City students performed the Dodogeran dance at the Bekasi City Square. The dancers were 3,317 people from 110 elementary schools throughout Bekasi City. This event successfully broke the Indonesian World Record
Museum Record (MURI) as the most dancer participants. The Dodogeran dance is still performed today. After getting the MURI record as the most participants, the Dodogeran dance is more often used for the welcoming dance at certain events. Because Dodogeran dance is a dance of creation that is rarely known to many people.

Today, art is often used as a means of entertainment. Through a long process, various types of dances emerge where each dance has its own function, With the change from entertainment to performances, the dance function then frees itself completely as a tool of interaction to socialization. Furthermore, when human aesthetic awareness becomes more intense, these forms of dance then become a source of inspiration for the creation of new works known as dance creations [9].

\section{Multiethnic Value in Dodogeran Dance}

The results of interviews conducted with the creator of the Dodogeran dance stated that this dance has three ethnic groups that are packaged into a dance namely ethnic Betawi, Sundanese and Chinese. The motion category ethnic show in table 1 .

TABLE I. MOTION CATEGORY ETHNIC

\begin{tabular}{|l|l|l|}
\hline No & \multicolumn{1}{|c|}{ Motion Motive } & \multicolumn{1}{c|}{ Ethnic } \\
\hline 1 & Puter Koma & Betawi \\
\hline 2 & Rapet Nindak & Betawi \\
\hline 3 & Pakblang & Sunda \\
\hline 4 & Koma Putes & Betawi \\
\hline 5 & Kagok puter & Betawi \\
\hline 6 & Nindak kagok goyang kaget & Betawi \\
\hline 7 & Nindak kagog lenggang & Betawi \\
\hline 8 & Ali alimudin & Betawi \\
\hline 9 & Broken & Betawi \\
\hline 10 & Gagahan & Betawi \\
\hline 11 & Silat & Adeg-adeg silat Sunda \\
\hline 12 & Kewer Variasi & Betawi \\
\hline
\end{tabular}

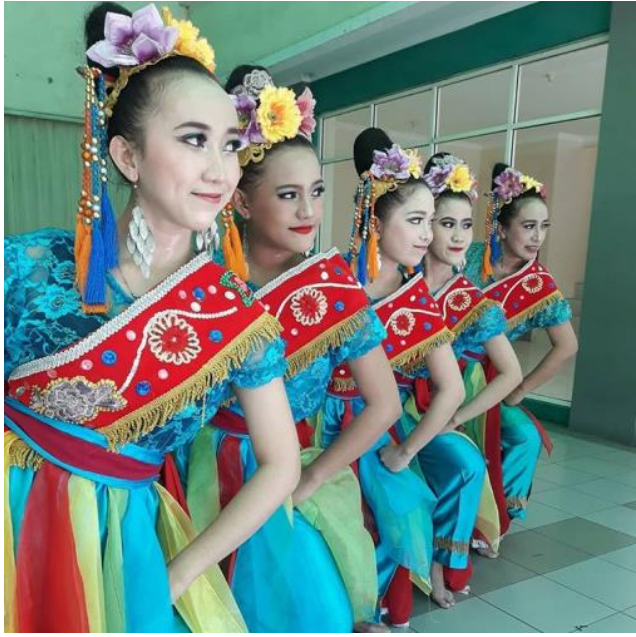

Fig. 1. Costume Dodogeran dance
Costume in Dodogeran dance like a figure 1, consists of short-sleeved balloon clothes, pangsi pants such as ethnic Sundanese, Betawi sash tokens, balloon cloth, raw andong raw materials such as ethnic Betawi, waist bands, bunny bun, large flowers and braid wool, skewers like ethnic ethnic groups Chinese. Dodogeran dance music adapts from a Betawi mask and fast tempo.

Every ethnic group in Indonesia still preserves these traditions as part of its cultural production. For example, learning the forms of dance from one ethnic group can help understand the culture of that ethnic group [10].

\section{CONCLUSION}

The multi-ethnic value in the Dodogeran dance in the seli asih ray studio can be seen from the variety of movements and clothing consisting of Sundanese, Betawi and Chinese ethnicities. The multi-ethnicity found in the Dodogeran dance is the result of cultural acculturation in Bekasi, which has many 
urban dwellers. These three ethnicities are the ones that mostly live in Bekasi City and are used as the basis of Dodogeran dance. The ethnic diversity that Bekasi has makes it its own identity. Bekasi City is one of the cities in the province of West Java, Indonesia. Currently Bekasi City has developed into a residence for urbanites and industrial centers. The culture in Bekasi city is quite diverse which has a mixture of several cultures. The geographical location of Bekasi City is between Sundanese, Betawi, and the legacy of Chinese culture, this causes the arts that are in Bekasi to be largely blended from various cultures found in Bekasi and produce cultural alkulturation.

\section{ACKNOWLEDGMENT}

Praise be to Allah SWT for the blessing of my article being completed. Thanks very much to Prof. Juju Masunah as the mentor for the writing of this article, who has spent for the guide research. Thanks also to the affiliation of the Universitas Pendidikan Indonesia which organized the International Conference On Arts and Design.

\section{REFERENCES}

[1] S. Ambarwangi, "Pendidikan Multikultural di Sekolah Melalui Pendidikan Seni Tradisi,“. Jurnal Harmonia Vol 13, 2013.
[2] J. Masunah, "Konsep dan Praktik Pendidikan Multikultural Di Amerika Serikat dan Indonesia,". Jurnal Ilmu Pendidikan, Jilid 17, Nomor 4.

[3] R. Faizah and Nurhafni, "Pendidikan Karakter Berbasis Multietnis pada Pembelajaran Bahasa Indonesia untuk Menghadapi di Era MEA,". Seminar Nasional Pendidikan Bahasa Indonesia 2015 ISSN: 2477-636X Universitas Mataram, 2015.

[4] B. Pratjichno, "Pendidikan Seni Sebagai Alternatif Pendidikan Multikultural,’. Jurnal Harmonia Vol 10, No 1, 2010.

[5] H. Darmadi, "Pendidikan Multi Budaya. Makalah Seminar Multi Budaya Bagi Guru - Guru Sekabupaten Sintang,” 2009

[6] Sugiyono, Metode Penelitian kuantitatif Kualitatif dan R \& D. Bandung : Alfabeta, 2017.

[7] T. Narawati, "Etnokoreologi : Pengkajian Tari Etnis \& Kegunaannya Dalam Pendidikan Seni,". Proceeding of the International Seminar On Languages and Art FBS Universitas Negeri Malang, 2013.

[8] R.M. Soedarsono, "Seni Pertunjukan Indonesia Di Era Globalisasi.Sumatera Barat,": Direktorat Jendral Pendidikan Tinggi, 1999.

[9] E. Caturwati, "Tari di Tatar Sunda,“. Bandung : Sunan Ambu Press Rias dan Busana Tari Sunda. Bandung : STSI PRESS Bandung, 2007.

[10] J. Masunah, "A case study of the multicultural practices of two United States dance educators : Implications for Indonesian K-9 dance education,". Disertasi, sekolah Pascasarjana Universitas Negeri Ohio, 2008 . 